\title{
IMPLEMENTASI PROGRAM BANTUAN PANGAN NON TUNAI (BPNT) DI KECAMATAN KANIGARAN KOTA PROBOLINGGO
}

\author{
Eko Yudianto Yunus \\ Jurusan Administrasi Negara \\ Fakultas Ilmu Sosial dan Ilmu Politik Universitas Panca Marga Probolinggo \\ Jl. Yos Sudarso No 107 Pabean, Dringu, Probolinggo \\ Email:
}

\begin{abstract}
Crucial food aid Examples of Non Cash (BPNT) Program is a program of food subsidies as a form of government efforts to increase food security and provide protection to poor families through the distribution of rice. Each family will receive Rp. 110.000, Imonth the point of distribution. Researchers take focus in Kecamatan Kanigaran Kota Probolinggo. In fact, implementation of BPNT policy is not always consider full-on procedure policy as depending on condition and situation in society. The objective of this study is to analyze the implementation of the Crucial food aid Examples of Non Cash program. This research uses qualitative descriptive method. Data collection was carried out with in-depth interviews from various informants have been determined. In qualitative research, data retrieved from various sources by using a technique of collecting data of which various (triangulation) and continuously until it is saturated. The result of this research is the determining factors of BPNT program implementation in, Kecamatan Kanigaran Kota Probolinggo caused by attitude factors (disposition) which is less successful in rice quality, target the household beneficiaries Crucial food aid Examples of Non Cash (BPNT), the number of households that received rice target beneficiaries.
\end{abstract}

Keywords: Non Cash Food Assistance Program; implementation

\begin{abstract}
Abstrak: Program Bantuan Pangan Non Tunai (BPNT) merupakan bantuan pangan sebagai bentuk upaya dari pemerintah untuk meningkatkan kesejahteraan dan pangan dan memberikan perlindungan bagi keluarga miskin melalui pendistribusian pangan yang diharapkan mampu menjangkau keluarga miskin, masing - masing keluarga menerima bantuan Rp. 110.000, .Peneliti mengambil lokus di Kecamatan Kanigaran Kota Probolinggo. Pada implementasi kebijakan bantuan BPNT ini dapat berjalan sesuai dengan aturan yang telah ditetapkan. Tujuan dari penelitian ini untuk menganalisis implementasi program Bantuan Pangan Non Tunai (BPNT) di Kecamatan Kanigaran Kota Probolinggo. Penelitian ini menggunakan metode kualitatif deskriptif. Pengumpulan data dilakukan dengan wawancara mendalam dari berbagai informan yang sudah ditentukan. Dalam penelitian kualitatif, data diperoleh dari berbagai sumber, dengan menggunakan teknik pengumpulan data yang bermacam-macam (triangulasi) dan dilakukan secara terus-menerus sampai datanya jenuh. Hasil penelitian ini adalah faktor penentu implementasi program BPNT di Kecamatan Kanigaran Kota Probolinggo disebabkan oleh faktor sikap (disposisi) kurang berhasil dalam kualitas beras, sasaran rumah tangga penerima manfaat BPNT, jumlah beras yang diterima rumah tangga sasaran penerima manfaat.
\end{abstract}

Kata Kunci: Program Bantuan Pangan Non Tunai; implementasi 


\section{PENDAHULUAN}

Kemiskinan merupakan salah satu permasalahan ekonomi yang ada di berbagai negara termasuk negara ini, dan kemiskinan merupakan permasalahan yang multidimensional. Ada banyak faktor yang melatarbelakangi kemiskinan, dan perlu dicarikan perspektif yang baru atau yang berbeda untuk melihat, menafsirkan, dan memaknai apa yang dinamakan dengan kemiskinan. kemiskinan Indonesia. Kemiskinan yang multidimensional ini mencakup kemiskinan dalam dimensi ekonomi, kemiskinan dalam dimensi sosial, politik, dan budaya kemiskinan dalam segala dimensi yang ada baik pendidikan, sejarah kemiskinan dalam dimensi sosio-politik (wacana), kemiskinan yang berdimensi pendidikan, agama, budi pekerti, serta kemiskinan dalam dimensi perdamaia dunia (hubungan bilateral atau diplomasi).

Isbandi Rukminto Adi (2003:1) dalam bukunya yang berjudul "Pemberdayaan Pengembangan Masyarakat Dan Intervensi Komunitas..." mengatakan bahwa proses pembangunan di Indonesia dipengaruhi oleh dua dimensi yaitu dimensi makro yang menggambarkan bahwa bagaimana perubahan suatu masyarakat dipengaruhi oleh institusi negara melalui kebijakan dan peraturan yang dibuatnya, sedangkan yang kedua adalah dimensi mikro yaitu proses pembangunan yang terjadi dipengaruhi oleh individu dan kelompok masyarakat itu sendiri.

Pendapat lain mengatakan bahwa kemiskinan terbagi dalam dua kategori yaitu kemiskinan kultural dan kemiskinan struktural. Kemiskinan kultural dimaknai sebagai akibat dari adanya karakter budaya dan etos kerja masyarakat yang lemah, sementara kemiskinan struktur dipandang sebagai akibat dari terjadinya ketidakadilan dalam kehidupan masyarakat yang disebabkan oleh kebijakan pemerintah yang timpang, (Syaiful Arif, 2000: 289).

Dari beberapa pendapat tersebut, antara Adi Isbandi Rukminto dan Syaiful Arif Dapat disimpulan bahwa dalam membangun masyarakat Indonesia agar mampu menggapai kesejahteraan dan pemberdayaan adalah dengan melibatkan semua unsur yang ada dalam sebuah negara, masyarakat, dan pemerintah. Pemerintah turut serta mempengaruhi perubahan sosial masyarakat dengan landasan keadilan sosial bagi seluruh rakyat Indonesia (strukturalmikro) Sedangkan disisi lain, masyarakat sebagai individu atau kelompok yang secara langsung mempengaruhi perubahan itu sendiri memerlukan keterbukaan budaya maupun peningkatan etos kerja yang selaras dan terarah (mikro-kultural).

Menurut data Badan Pusat Statistik (BPS) Nasional. Pada tahun 2009 jumlah penduduk miskin di Indonesia sebesar 29,89 juta atau 12,36\% dari total penduduk Indonesia yang tersebar diberbagai provinsi yang ada di Indonesia, hal itu mengalami penurunan angka kemiskinan pada tahun 2014 menjadi 28,28 juta orang atau 11,25\% dari total penduduk. Dari data tersebut, Indonesia telah mengeluarkan berbagai program untuk memberantas kemiskinan yang telah berurat-berakar di Indonesia. Di antarnya, Program Keluarga Harapan (PKH). Pengentasan Kemiskinan (Bantuan Langsung Tunai (BLT), Kredit Usaha Rakyat (KUR) dll,

Sementara menurut Badan Pusat Statistik (BPS) Kota Probolinggo, jumlah penduduk miskin (penduduk yang berada di bawah Garis Kemiskinan) di Kota Probolinggo pada tahun 2013 sebesar 17,35\% dari jumlah penduduk 219.139 yang tersebar di 5 kecamatan yang ada di Kota Probolinggo. Hal tersebut lebih rendah dari angka kemiskinan pada tahun 2011 pada angka $17,74 \%$. Dalam rangka percepatan penanggulangan kemiskinan seperti yang digambarkan di atas, sekaligus pengembangan kebijakan di bidang perlindungan sosial, Pemerintah Indonesia mulai tahun 2007 telah melaksanakan Program Bantuan Pangan Non Tunai (BPNT). BPNT dikenal di negara lain dengan istilah Non Cash Food Assistance Program . 
BPNT bukan merupakan kelanjutan program Subsidi Langsung Tunai yang diberikan dalam rangka membantu rumah tangga miskin mempertahankan daya belinya pada saat pemerintah melakukan penyesuaian harga BBM. BPNT lebih dimaksudkan pada upaya membangun sistem perlindungan (keberdayaan pangan) sosial kepada masyarakat miskin. Pelaksanaan di Indonesia diharapakan akan membantu penduduk termiskin, bagian masyarakat yang paling membutuhkan uluran tangan dari siapapun juga. Pelaksanaan BPNT secara berkesinambungan setidaknya hingga tahun 2019 akan mempercepat pencapaian Tujuan Pembangunan Milenium. Bantuan Pangan Non Tunai (BPNT) merupakan program pemerintah pusat untuk membantu masyarakat miskin yang rawan pangan, agar mereka mendapatkan bahan pangan untuk kebutuhan rumah tangganya.

Program BPNT merupakan bagian dari program penanggulangan kemiskinan yang ada pada Kluster pertama, yaitu tentang kegiatan perlindungan sosial berbasis keluarga dalam pemenuhan kebutuhan pangan pokok bagi masyarakat kurang mampu. Program Bantuan Pangan Non Tunai mulai dilaksanakan dan disalurkan pada tahun 2017 di 44 kota yang memiliki akses dan fasilitas memadai. Secara bertahap, bantuan pangan akan diperluas ke seluruh kota dan kabupaten sesuai dengan kesiapan sarana dan prasarana penyaluran non tunai. Mulai tahun 2018 bantuan pangan akan disalurkan ke masing-masing kabupaten/kota dalam bentuk non tunai atau natura, yaitu tetap dalam bentuk beras dan atau Telor.

Pemerintah memiliki kepedulian terhadap penanggulangan kemiskinan secara khusus dituangkan dalam Peraturan Menteri Sosial Republik Indonesia Nomor 25 Tahun 2016 tentang Bantuan Pengembangan Sarana Usaha Melelui Elektronik Warung pada Pasal 1 ayat 1 sebagai berikut:

"Penanganan Fakir miskin adalah upaya yang terarah. Terpadu dan berkelanjutan yang dilakukan Pemerintah, Pemerintah Daerah dan masyarakat dalam bentuk kebijakan, program, serta fasilitas untuk memenuhi kebutuhan dasar setiap warga Negara."

Peraturan menteri tersebut menciptakan sebuah inovasi atau program baru untuk program Bantuan yang bernama Bantuan Pangan Non Tunai. Bantuan Pangan Non Tunai adalah bantuan sosial pangan dalam bentuk non tunai dari pemerintah yang diberikan kepada Keluarga Penerima Manfaat setiap bulannya melalui mekanisme akun elektronik yang digunakan hanya untuk membeli bahan pangan di pedagang bahan pangan E-Warong (Elektronik Warung Gotong Royong) dan RPK (Rumah Pangan Kita) yang bekerjasama dengan Bank penyalur (Pedoman Pelaksanaan BPNT). Bantuan Pangan Non Tunai ini bertujuan untuk mengurangi beban pengeluaran KPM melalui pemenuhan sebagai kebutuhan pangan, memberikan nutrisi yang lebih seimbang kepada KPM, meningkatkan ketepatan sasaran dan waktu penerimaan Bantuan Pangan bagi KPM, memberikan lebih banyak pilihan dan kendali kepada KPM dalam memenuhi kebutuhan pangan dan mendorong pencapaian Tujuan Pembangunan Berkelanjutan (Sustainable Development Goals/SDGs).

Para Keluarga Penerima Manfaat Bantuan Pangan Non Tunai adalah keluarga, yang selanjutnya disebut Keluarga Penerima Manfaat (KPM) Bantuan Pangan Non Tunai. KPM adalah penduduk dengan kondisi sosial ekonomi 25\% terendah di daerah pelaksanaan. Besaran Bantuan Pagan Non Tunai adalah Rp. 110.000,-/KPM/bulan. Bantuan tersebut tidak dapat diambil tunai dan hanya dapat ditukarkan dengan beras dan atau telur di E-Warong (Elektronik Warung Gotong Royong) \& RPK (Rumah Pangan Kita). apabila bantuan tidak dibelanjakan dibulan tersebut, 
maka nilai bantuan akan hangus dalam akun elektronik Bantuan Pangan. E-Warong ini dikelola Ketua dan anggota yang berjumlah sepuluh orang sesuai dengan kriteria dan persyaratatan pada pasal 4 ayat 1 Permensos RI Nomor 25 Tahun 2016 tentang Kriteria Pembentukan E-Warong, sedangkan RPK (Rumah Pangan Kita) merupakan mitra Perum Bulog serta jaringan outlet penjualan pangan pokok yang dimiliki oleh masyarakat dan dibina oleh Perum Bulog. Berdasarkan uraian latar belakang diatas, untuk meninjau Implementasi Kebijakan Percepatan Penerbitan Akta Kelahiran Dengan Berbasis Teknologi Informasi Dan Komunikasi pada Dinas Kependudukan dan Pencatatan Sipil, maka peneliti menggunakan teori Van Metter dan Van Carl Horn yang meliputi 6 faktor yang berpengaruh dalam implemementasi program yaitu ukuran dan tujuan kebijakan, sumber daya, karakteristik para pelaksana, sikap/kecenderungan para pelaksana, komunikasi antarorganisasi dan aktivitas pelaksana dan lingkungan ekonomi, sosial, dan politik. Berdasarkan latar belakang tersebut, maka tujuan dari penelitian ini adalah untuk menganalisis Implementasi Program Bantuan Pangan Non Tunai di Kecamatan Kanigaran Kota Probolinggo. Tujuan kedua adalah untuk mendeskripsikan faktor pendukung dan penghambat Implementasi Program Bantuan Pangan Non Tunai (BPNT) Kelurahan Kanigaran Kecamatan Kanigaran Kota Probolinggo.

\section{METODE PENELITIAN}

Dalam penelitian ini jenis penelitian yang digunakan adalah penelitian deskriptif dengan pendekatan kualitatif. Sedangkan fokus penelitiannya menggunakan teori Van Metter dan Van Carl Horn yang meliputi 6 faktor yang berpengaruh dalam implemementasi program yaitu ukuran dan tujuan kebijakan, sumber daya, karakteristik para pelaksana, sikap/kecenderungan para pelaksana, komunikasi antarorganisasi dan aktivitas pelaksana dan lingkungan ekonomi, sosial, dan politik.

Teknik pengumpulan data yang digunakan dalam penelitian Implementasi Bantuan Pangan Non Tunai (BPNT) di Kecamatan Kanigaran Kota Probolinggo adalah wawancara, observasi, dan dokumentasi. Sedangkan teknik analisis datanya menggunakan model Miles dan Huberman (dalam Silalahi, 2012) yang terdiri dari pengumpulan data, reduksi data, penyajian data dan penarikan kesimpulan.

\section{HASIL DAN PEMBAHASAN}

Kebijakan pemerintah pusat dalam menangani kemiskinan oleh Kementerian Sosial yang dilaksanakan di Kota Probolinggo pada khususnya adalah Program Bantuan Pangan Non Tunai (BPNT), melalui beberapa penyalur BPNT di Kecamatan Kanigaran yang dimulai sejak tahun 2016. Program Bantuan Pangan Non Tunai (BPNT), sebuah program yang gagas oleh Menteri Sosial yaitu Khofifah Indar Parawansa. Berdasarkan penelitian yang telah dilakukan, maka hasil penelitian terkait dengan Implementasi Bantuan Pangan Non Tunai (BPNT) yang dianalisis menggunakan teori Van Metter dan Van Horn dengan enam variabel yaitu ukuran dan tujuan kebijakan, sumber daya, karakteristik para pelaksana, sikap/kecenderungan para pelaksana, komunikasi antarorganisasi dan aktivitas pelaksana dan lingkungan ekonomi, sosial, dan politik adalah sebagai berikut:

1. Ukuran dan Tujuan Kebijakan Apabila standart, tujuan dan sasaran kebijakan tidak tecapai akan terjadi multi interpretasi dan sangatlah penting karena tanpa adanya kerja sama dari aktor pelaksana tentunya kebijakan tidak akan berjalan dengan baik. Program ini juga yang menentukan sukses tidaknya adalah pemerintah kelurahan, karena program ini diterapakan 
di setiap kelurahan. Sumber daya finansial atau dana pada program Bantuan Pangan Non Tunai ini berasal dari Kementrian Sosial yang langsung di transfer ke rekening-rekening KPM sebesar Rp 110.000,-/bulan. Untuk sumber daya dana sudah sesuai dengan yang ditentukan dalam pedoman pelaksanaan Bantauan Pangan Non Tunai (BPNT), Sumber daya waktu untuk pelaksanaan Bantuan Pangan Non Tunai sudah efektif, karena uang yang tersalurkan setiap bulan tidak ada kendala. Sumber daya fasilitias sendiri mengalami kendala yaitu pada mesin EDC yang sering terjadi gangguan, sehingga proses implementasi terganggu. Dan dapat menjadi faktor penghambat jalannya implementasi Bantuan Pangan Non Tunai (BPNT)

2. Karakteristik Agen Pelaksana Berdasarkan hasil penelitian yang sudah dilakukan, yaitu karakteristik yang ada pada aktor pelaksana Kelurahan dimana aktor pelaksana yang tegas, disiplin, baik dan ramah kepada setiap masyarakat. Untuk karakteristik yang ideal dalam program Bantuan Pangan Non Tunai (BPNT) di Kecamatan Kanigaran Kota Probolinggo. Untuk mengetahui peneliti melalukan observasi lapangan dan wawancara pada beberapa KPM untuk mengetahui bagaimana karakteristik pada masing-masing aktor pelaksana di tingkat Kelurahan. Hasilnya adalah para aktor pelaksana mulai dari pak Lurah, Pendamping, Koordinator Kelurahan dan Ketua E-Warong dan RPK. Dari hasil lapangan dan wawancara sudah memenuhi standar yaitu masing-masing aktor memiliki sifat yang sudah tertera dalam UU No. 25 Tahun 2009. Salah satunya berbunyi pelaksanaan pelayanan publik harus berperilaku santun dan ramah,karena tidak memiliki sifat yang dimiliki aktor lain.

3. Sikap/Kecenderungan Para Pelaksana Pelaksana yang terlibat dalam program ini khususnya di Kecamatan Kanigaran sudah menjalankan tugas, pokok dan fungsinya masing-masing. Hanya saja terdapat beberapa pelaksana yang tidak ramah dalam melayani masayarakat. Sehingga masyarakat merasa tidak nyaman atas sikap pelaksana tersebut. Semua pelaksana yang terlibat sebenarnya sudah menjalankan tupoksinya masing-masing hanya saja ada pihak implementor enggan melakukan tugas yang diembannya. Justru yang dilakukan salah satu implementor adalah hal yang menyimpang. Hal ini tidak dapat melakukan salah satu poin pada disposisi implementor respon implementor terhadap kebijakan yang akan mempengaruhi kemauannya untuk melaksanakan kebijakan. Implementor yang lain juga bersikap tidak bertanggung jawab atas tugasnya. Sehingga masalah yang terjadi pada mesin EDC menjadi keluhan masyarakat.

4. Komunikasi Antar Organisasi Didalam pelaksanaan program Bantuna Pangan Non Tunai (BPNT) melalui E-Warong \& RPK di Kecamatan Kanigaran Kota Probolinggo pada awal implementasi program tidak terjadi miskomunikasi antar aktor dari tingkat Kelurahan maupun pusat. Karena sebelumnya pelaksanaan program dari Kementrian Sosial sudah memberikan sosialisasi yang cukup baik sebagai tujuan dan sasaran dari program Bantuan Pangan Non Tunai (BPNT) melalui E-Warung \& RPK di Kecamatan Kanigaran Kota Probolinggo. Hasil sosialisasi disampaikan kepada masyarakat Keluarga Penerima Manfaat di Kecamatan Kanigaran agar masyarakat mengetahui secara rinci isi dari program Bantuan Pangan Non Tunai(BPNT) melaui E-Warung \& RPK. Untuk penyampaian sosialisasi pada KPM yang dilakukan dikelurahan dan disampaiakan oleh pihak Dinas Sosial dan dibantu oleh para pendamping BPNT. Pada saat sebelum bantuan disalurkan ke semua KPM, dikumpulkan di kelurahan dan dijelaskan secara rinci mengenai bantuan BPNT baik tujuan dari progam ini maupun sasaran dari program Bantuan Pangan Non 
Tunai (BPNT) yang disalurkan melaui E-Warong \& RPK ini. Tidak hanya itu, pendamping juga melakukan sosialisasi secara rutin pada saat transaksi program Bantuan agar masyarakat paham. Sehingga komunikasi antar organisasi terjalin dengan baik.

5. Secara Lingkungan Ekonomi, Sosial dan Politik. Jika dilihat dari segi sosial masyarakat sangat merespon adanya program BPNT, mereka sangat mendukung dengan adanya program ini. Hal itu dapat dilihat dari respon masyarakat setempat yang tidak mendapatkan program juga ikut membantu dalam proses pengadaan barang di E-Warung. Masyarakat ikut membantu mengangkat dan menata barang- barang yang dibeli oleh para pihak pelaksana. Hanya saja karena keadaan masyarakat masih banyak yang berpendidikan rendah dan lansia sehingga tidak dapat menggunakan ATM/kartu combo. Hal ini menjadi hambatan dalam pelaksanaannya sebab program ini menggunakan ATM/kartu kombo sebagai alat transaksi penyalurannya. Berdasarkan hasil penelitian, tujuan program Bantuan Pangan Non Tuna (BPNT) melalui E-Warung/RPK di Kecamatan Kanigaran Kota Probolinggo adalah salah satu tujuan yaitu meningkatkan ketepatan sasaran dan waktu penerimaan Bantuan pangan bagi KPM belum terlaksana karena ada masalah yang terjadi pada mesin EDC sehingga menyebabkan pada salah satu tujuan Bantuan Pangan Non Tunai (BPNT) tidak terealisasi yaitu meningkatkan ketetapan sasaran dan waktu penerimaan Bantuan Pangan bagi KPM. karena dengan terjadinya masalah pada mesin EDC menyebabkan ketidak efektifan penyaluran.

6. Sumber daya di dalam implementasi kebijakan diperlukan dukungan sumber daya baik sumber daya manusia maupun sumber daya non manusia. Kemampuan memanfaatkan sumber daya yang tersedia juga akan mempengaruhi keberhasilan proses implementasi kebijakan. Tanpa adanya dukungan sumber daya manusia, sumber daya financial dan sumber daya waktu tentunya sebuah kebijakan tidak akan berjalan sesuai dengan apa yang diinginkan. Sumber daya manusia yang paling peting didalam implementasi kebijakan. Dibutuhkan sumber daya yang kompeten didalam pelaksanaan program agar tujuan dari kebijakan dapat tercapai. Kepala Seksi Penyuluhan dan Bimbingan Sosial menyebutkan bahwa banyak aktor yang terkait dalam program ini. Program Bantuan Pangan Non Tunai (BPNT) melalui E-Warong \& RPK di Kecamatan Kanigaran Kota Probolinggo, Tentunya keberhasilan pelaksana program tidak terlepas dari aktor- aktor lingkup kelurahan dan pendamping. Aktor pelaksana yang terdiri dari pendamping BPNT, Koordinator di kelurahan dan lurah serta masyarakat setempat yang ikut membantu dalam program Bantuan Pangan Non Tunai (BPNT) melalui E-Warong \& RPK di Kecamatan Kanigaran Kota Probolinggo.

\section{A. Ukuran dan tujuan kebijakan apabila berstandart pada tujuan dan sasaran kebijakan bila tidak tecapai akan terjadi multi interpretasi.}

mudah tejadi konflik diantara para agen implementor, sehingga dalam pelaksanaan program Bantuan Pangan Non Tunai (BPNT) melalui E-Warong \& RPK di Kecamatan Kanigaran Kota Probolinggo dapat berjalan dengan baik. Berdasarkan hasil penelitian, tujuan program Bantuan Pangan Non Tuna (BPNT) melalui E-Warong \& RPK di Kecamatan Kanigaran Kota Probolinggo ada salah satu tujuan yaitu meningkatkan ketepatan sasaran dan waktu penerimaan Bantuan pangan bagi KPM belum terlaksana karena ada masalah yang terjadi pada mesin EDC sehingga menyebabkan pada salah satu tujuan Bantuan Pangan Non Tunai (BPNT) tidak terealisasi yaitu meningkatkan ketetapan sasaran dan waktu penerimaan Bantuan Pangan 
bagi KPM. karena dengan terjadinya masalah pada mesin EDC menyebabkan ketidak efektifan penyaluran.

\section{B. Sumber Daya Didalam implementasi kebijakan diperlukan dukungan sumber daya baik sumber daya manusia maupun sumber daya non manusia.}

Kemampuan memanfaatkan sumber daya yang tersedia juga akan mempengaruhi keberhasilan proses implementasi kebijakan. Tanpa adanya dukungan sumber daya manusia, sumber daya financial dan sumber daya waktu tentunya sebuah kebijakan tidak akan berjalan sesuai dengan apa yang diinginkan. Sumber daya manusia merupakan hal yang paling peting didalam implementasi kebijakan. Dibutuhkan sumber daya yang kompeten didalam pelaksanaan program agar tujuan dari kebijakan dapat tercapai. Kepala Seksi Penyuluhan dan Bimbingan Sosial menyebutkan bahwa banyak aktor yang terkait dalam program ini. Program Bantuan Pangan Non Tunai (BPNT) melalui E-Warong \& RPK di Kecamatan Kanigaran Kota Probolinggo. Tentunya keberhasilan pelaksana program tidak terlepas dari aktor- aktor lingkup kelurahan seperti Kepala Kelurahan. Aktor pelaksana yang terdiri dari pendamping PKH dan pendamping BPNT serta Koordinator di kelurahan dan masyarakat setempat yang ikut membantu dalam program Bantuan Pangan Non Tunai (BPNT) melalui E-Warong \& RPK di Kecamatan Kanigaran Kota Probolinggo.

Sangatlah penting karena tanpa adanya kerja sama dari aktor pelaksana tentunya kebijakan tidak akan berjalan dengan baik. Program ini juga yang menentukan sukses tidaknya penyaluran BPNT ini adalah pemerintah kelurahan dan Kecamatan, karena program ini diterpakan di area setiap kelurahan. Sumber daya finansial atau dana pada program Bantuan Pangan Non Tunai ini berasal dari Kementrian Sosial yang langsung di transfer ke rekeningrekening KPM sebesar Rp 110.000,-/bulan. untuk sumber daya dana sudah sesuai dengan yang ditentukan dalam pedoman pelaksanaan Bantauan Pangan Non Tunai (BPNT). Sumber daya waktu untuk pelaksanaan Bantuan Pangan Non Tunai sudah efektif, karena uang yang tersalurkan setiap bulan tidak ada kendala. Sumber daya fasilitias sendiri mengalami kendala yaitu pada mesin EDC yang sering terjadi gangguan, sehingga proses implementasi terganggu. Dan dapat menjadi faktor penghambat jalannya implementasi Bantuan Pangan Non Tunai (BPNT).

\section{Karakteristik Agen Pelaksana Berdasarkan hasil penelitian yang sudah dilakukan di e- warong dan RPK di Kecamatan Kanigaran adalah aktor pelaksana yang tegas, disiplin, baik dan ramah kepada setiap masyarakat.}

Untuk karakteristik dalam pelaksanaan program Bantuan Pangan Non Tunai (BPNT) melalui E-Warung \& RPK di Kecamatan Kanigaran Kota Probolinggo menunjukkan karakteristik yang ideal dalam keberhasilan menjalankan program ini. Untuk mengetahui itu, peneliti telah melalukan observasi lapangan dan wawancara pada beberapa KPM untuk mengetahui bagaimana karakteristik pada masing-masing aktor pelaksana di tingkat Kecamatan. Hasilnya adalah para pelaksana mulai dari Kepala Kelurahan, Pendamping BPNT, Ketua E-Warong dan RPK di lapangan sudah memenuhi standar dalam pelaksanaannya. Dari para pelaksana program memiliki sifat yang sudah tertera dalam UU No. 25 Tahun 2009. Salah satunya berbunyi pelaksanaan pelayanan publik harus berperilaku santun dan ramah. Hanya saja ada beberapa oknum pelaksana yang tidak memenuhi standar seperti yang dilakukan oleh pelaksana-pelaksana lain pada program ini. 


\section{Sikap/Kecenderungan Para Pelaksana-Pelaksana yang terlibat dalam program ini khususnya di Kecamatan Kanigaran sudah menjalankan tugas, pokok dan fungsinya masing-masing.}

Hanya saja terdapat beberapa pelaksana yang kurang ramah dalam melayani KPM pada saat penyaluran bantuan, sehingga penerima merasa tidak nyaman atas sikap pelaksana tersebut. Semua pelaksana yang terlibat sebenarnya sudah menjalankan tupoksinya masing-masing hanya saja ada pihak pelaksanan enggan melakukan tugas yang diembannya. Justru yang dilakukan salah satu pelaksana program ini adalah hal yang menyimpang. Hal ini tidak dapat melakukan salah satu poin pada disposisi implementor respon implementor terhadap kebijakan yang akan mempengaruhi kemauannya untuk melaksanakan kebijakan. Implementor yang lain juga bersikap tidak bertanggung jawab atas tugasnya. Sehingga masalah yang terjadi pada mesin EDC menjadi keluhan bagi penerima / KPM.

\section{E. Komunikasi Antar Organisasi Didalam pelaksanaan program Bantuna Pangan Non Tunai (BPNT) melalui E-Warong \& RPK di Kecamatan Kanigaran Kota Probolinggo.} pada awal implementasi program ini tidak terjadi miskomunikasi antar aktor pelaksanan dari tingkat kelurahan maupun pusat, karena sebelum berjalannya program dari Kementrian Sosial ini sudah memberikan sosialisasi baik standar, tujuan dan sasaran terhadap program Bantuan Pangan Non Tunai (BPNT) melalui E-Warung \& RPK di Kecamatan Kanigaran Kota Probolinggo. Hasil sosialisasi yang telah dilaksanakan kepada masyarakat di lingkup Kecamatan Kanigaran yang dilakukan di tiap tiap kelurahan dan pertemuan-pertemuan warga serta kelompok-kelompok penerima bantuan yang lain agar masyarakat mengetahui secara rinci isi dari program Bantuan Pangan Non Tunai (BPNT) yang dilaksanakan melaui E-Warung \& RPK. Untuk penyampaian sosialisasi pada KPM dilakukan di setiap kelurahan yang disampaiakan oleh pihak Dinas Sosial dan dibantu oleh para pendamping BPNT dan PKH. Pada saat ini semua KPM dikumpulkan di kelurahan dan dijelaskan secara menyeluruh perihal bantuan BPNT serta mengenai standar, tujuan dan sasaran dari program Bantuan Pangan Non Tunai (BPNT) yang disalurkan melaui E-Warong \& RPK ini. Tidak hanya itu, pendamping BPNT \& TKSK (Tenaga Kesejahteraan Sosial Kecamatan) juga melakukan sosialisasi secara rutin dalam kelompokkelompok penerima bantuan lain pada saat transaksi. Jika dilihat dari segi sosial masyarakat sangat merespon adanya program, mereka sangat mendukung dengan adanya program ini. Karena dapat dilihat dari respon masyarakat setempat yang tidak mendapatkan program juga ikut membantu dalam proses penyaluran komoditi di E-Warong \& RPK. Kelompok-kelompok masyarakat yang mendapatkan bantuan lain juga ikut membantu menyiapkan komoditas barangbarang yang akan disalurkan oleh para pihak pelaksana. Hanya saja dari kondisi warga yang hendak membantu dalam penyaluran bantuan memiliki keadaan yang kurang mendukung dalam menjalankan prosesnya, ada beberapa orang yang buta huruf dan lansia dan memiliki pendidikan yang rendah sebagai penghambat dalam membantu kelancaran penyaluran program ini di ewarong dan RPK, sehingga pada transaksinya proses penyaluran tidak dapat berjalan dengan baik karena tidak dapat menggunakan ATM, hal ini menjadi hambatan karena program ini menggunakan ATM sebagai sarana transaksi.

Melalui program Bantuan Pangan Non Tunai (BPNT) Pemerintah menyediakan bantuan dalam bentuk uang non tunai sebesar Rp. 110.000 yang tidak dapat di cairkan dalam bentuk uang, tetapi dalam bentuk beras $10 \mathrm{Kg}$ dan telur 10 Butir yang dapat diambil di E-Warong (Elektronik Warong Gotong Royong khusus untuk program BPNT) yang mana lebih dikhususkan sebagai 
tempat penyaluran Bantuan BPNT disamping pemberdayaan komoditi selain selain beras dan telor yang dilakukan oleh kube jasa. Keberhasilan program Bantuan Pangan Non Tunai (BPNT) diukur berdasarkan tingkat pencapaian indikator 6T, yaitu Tepat sasaran, Tepat jumlah, Tepat harga, Tepat waktu, Tepat kualitas, dan Tepat administrasi.

1. Tepat sasaran adalah program Bantuan Pangan Non Tunai (BPNT) hanya diberikan kepada rumah tangga miskin. Secara aturan penerima bantuan BPNT merupakan penerima yang diambil dari data BDT (Basic Data Terpadu) Kementerian Sosial RI yang artinya bahwa secara regulasi mereka termasuk keluarga miskin.

2. Tepat jumlah adalah beras dan telur untuk setiap Kepala Keluarga (KK) dalam perbulan. Berdasarkan hasil data yang didapat di lapangan menunjukan bahwa 2484 penerima/KPM atau $100 \%$ menerima program BPNT berupa beras $10 \mathrm{Kg}$ (Beras Medium) dan telur 10 Butir telor ayam.

3. Tepat harga adalah harga beras dan telur yang diberikan kepada KPM sesuai dengan yang ditetapkan oleh pemerintah yaitu gratis tidak dipungut biaya. Serta bantuan yang diterima berupa beras dan Telor itu sudah disesuaikan dengan jumlah bantuan yang masuk di dalam ATM Combo setiap penerima sejumlah Rp. 110.000,-

4. Tepat waktu adalah pembagian beras dan telur dilaksanakan sesuai dengan jadwal yang sudah ditetapkan oleh pihak Kementerian Sosial dan berkoordinasi dengan bank penyalur

5. Tepat kualitas adalah kualitas beras dan telur layak untuk dikonsumsi. Komoditas BPNT berupa beras dan telor yang didapat KPM haruslah tepat secara kualitas.

6. Tepat administrasi adalah terpenuhinya persyaratan administrasi secara benar dan tepat waktu.

Dalam ketepatan kebijakan ini dinilai dari sejauh mana kebijakan yang ada telah bermuatan hal-hal yang memang memecahkan masalah yang hendak dipecahkan dalam how excelent is the policy (Nugroho, 2011:650). Adapun ketepatan kebijakan tersebut dapat dinilai dari beberapa hal yaitu :

1. Intensitas Tujuan Menurut pedoman umum BPNT didalam pelaksanaan program BPNT, Tujuan dari program BPNT adalah mengurangi beban pengeluaran Rumah Tangga Sasaran melalui pemenuhan sebagian kebutuhan pangan pokok bentuk beras dan atau telor. Selain itu BPNT juga bertujuan untuk meningkatkan atau membuka akses pangan keluarga melalui penjualan beras kepada keluarga penerima manfaat dengan jumlah yang telah ditentukan. Hasil interview yang dilakukan oleh Peneliti dapat diketahui bahwa tujuan dari program BPNT dinilai kurang sesuai, karena sasaran yang menjadi tujuan tidak sepenuhnya mendapatkan komoditi dengan ketentuan yang diharapkan. Rumah Tangga Sasaran yang seharusnya dapat memilih komoditas yang telah disesuaikan dengan bantuan yang telah masuk kedalam kartu combo sebesar Rp. 110.000,- untuk mendapatkan komoditas yang diharapkan baik secara kualitas ataupun kuantitas sesuai harapan penerima, kenyataannya komoditas sudah ditentukan baik secara kualitas ataupun kuantitas oleh pihak penyalur. Sehingga dalam hal ini dapat disimpulkan bahwa ketepatan kebijakan dalam program BPNT ini belum sepenuhnya sesuai dengan tujuan dari pedoman umum BPNT.

2. Ketepatan Pelaksanaan. Ketepatan Aktor Pelaksana Aktor implementasi kebijakan tidaklah hanya pemerintah. Ada tiga lembaga yang bisa menjadi pelaksana, yaitu pemerintah, kerjasama antara pemerintah- masyarakat/swasta, atau implementasi kebijakan yang 
diswastakan (privatization atau cintracting out) (Nugroho, 2011:650). Dalam Pedoman Umum BPNT telah dijelaskan aktor-aktor yang terlibat dalam melaksanakan program ini. Dalam Pedoman Umum BPNT agar mencapai tujuan yang telah ditentukan dibentuklan Tim Koordinasi di setiap Kota, Kecamatan maupun Kelurahan Hasil interview yang dilakukan oleh peneliti dapat diketahui bahwa tim pelaksana Program BPNT sudah dibentuk sesuai dengan tingkatannya. Ketepatan Tugas Pelaksana Hasil interview yang dilakukan oleh peneliti dapat diketahui bahwa tim pelaksana Program BPNT sudah melaksanakan tugasnya sesuai dengan tugas-tugas yang ditentukan oleh pedoman umum BPNT. Seperti tim kabupaten / kota, tim kecamatan dan tim kelurahan sudah menjalankan tugasnya dalam pengimplementasian program BPNT. Tim pelaksana Program BPNT di kabupaten / kota, kecataman dan kelurahan, sudah melakukan koordinasi perencanaan, anggaran, sosialisasi, pelaksanaan penyaluran, monitoring dan evaluasi, menerima pengaduan, melakukan penyaluran hingga titik distribusi dengan baik atau sudah sesuai dengan tugasnya masing-masing. Keterlibatan para tim pelaksana BPNT kota, kecamatan dan kelurahan memudahkan berjalannya programnya di lingkup Kecamatan Kanigaran. Para aktor yang terlibat juga sudah mengetahui dan sudah memahami tugas masingmasing. Sehingga implementasi program BPNT yang berjalan di Kecamatan Kanigaran bisa dikatakan berhasil.

3. Ketepatan Target, Penerima Pada tahun 2013 pemerintah menerapkan kebijakan baru dalam sistem pendataan RTS yang dilakukan oleh Tim Nasional Percepatan Penanggulangan Kemiskinan (TNP2K). Program BPNT termasuk dalam klaster satu yaitu yaitu kelompok program penanggulangan kemiskinan bantuan sosial terpadu berbasis keluarga. Tujuannya untuk melakukan pemenuhan hak dasar, pengurangan beban hidup, serta perbaikan kualitas hidup masyarakat miskin. Fokus pemenuhan hak dasar ditujukan untuk memperbaiki kualitas kehidupan masyarakat miskin untuk kehidupan lebih baik, seperti pemenuhan hak atas pangan, pelayanan kesehatan dan pendidikan. (dalam http://tnp2k.go.id/program/kl aster-i-2/) Dalam ketepatan target peneliti lebih memilih permasalahan pada ketepatan target yang mencakup dalam apakah penerima target ini sudah mengetahui ketentuan yang harus dipatuhi dalam pelaksanaan program BPNT. Pada kenyataannya ketepatan target yang terjadi di Kecamatan Kanigaran belum berjalan sesuai dengan pedoman umum BPNT. Sebab masyarakat penerima di Kecamatan Kanigaran yang tidak termasuk dalam data BDT (Basic Data Terpadu) merasa berhak mendapatkan BPNT juga. Sehingga yang menjadi tujuan dari program BPNT tidak bisa tercapai sepenuhnya.

4. Ketepatan Proses (1). Kesiapan Pelaksana dalam Menjalankan Kebijakan Menurut pedoman umum BPNT, program ini sangat strategis dan menjadi program nasional yang dikelola secara lintas strategis dan program nasional yang dikelola secara lintas sektoral baik vertikal maupun horizontal. Seluruh Kementrian/lembaga terkait baik pusat maupun di daerah mengambil bagian tugas dan tanggung jawan dalam melaksanakan program ini, sesuai dengan tugas, pokok dan fungsi masing-masing. Pemerintah pusat berperan dalam pembuat kebijakan program, sedangkan pelaksanaannya sangat bergantung kepada pemerintah Daerah. Oleh karena itu, peran Pemerintah Daerah sangat penting dalam peningkatan efektifitas program BPNT, yang diwujudkan dalam 6 (enam T) Tepat. Dalam hal ini tim pelaksana program BPNT di tingkat Kota, Kecamatan dan kelurahan menyatakan bahwa siap menjalankan program BPNT yang diberikan dari pemerintah pusat. Pemerintah daerah juga harus melaksanakan program BPNT sesuai dengan pedoman 
umum untuk mencapai tujuan dari program BPNT dan memenuhi indikator 6 (enam) tepat yang menjadi tolak ukur keberhasilan program BPNT. (2). Kesiapan masyarakat dalam Menjalankan Kebijakan Penerima manfaat pada kelompok program penanggulangan kemiskinan berbasis bantuan dan perlindungan sosial ditujukan pada kelompok masyarakat sangat miskin. Hal ini disebabkan bukan hanya karena kondisi masyarakat sangat miskin yang bersifat rentan, akan tetapi juga karena mereka belum mampu mengupayakan dan memenuhi hak dasar secara layak dan mandiri.( http://tnp2k.go.id/program/kl aster-i-2/) Tujuan dan sasaran dari program raskin untuk wilayah Kecamatan Kanigaran Kota Probolinggo tidak dipatuhi oleh masyarakat setempat. Maka dari itu terjadi ketidaksiapan masyarakat dalam menjalankan program BPNT. Selain itu bisa dilihat dari masyarakat yang bukan KPM tetapi ingin mendapatkan bantuan juga. Sehingga dapat dikatakan bahwa program BPNT di Kecamatan Kanigaran Kota Probolinggo masyarakatnya belum siap menjalankan program BPNT.

Keberhasilan dari implementasi suatu kebijakan akan ditentukan oleh banyak variabel atau faktor, dan masing-masing variabel tersebut saling berhubungan satu sama lain. (Sudarsono. 2005: 89-101) Teori George C. Edwards III (1980) Dalam pandangan Edwards III, implementasi kebijakan dipengaruhi oleh empat variabel, yakni:

1. Komunikasi diperlukan adanya komunikasi yang baik dari setiap implementor dalam mengimplementasikan kebijakan ini.

2. Sumberdaya Suatu nilai potensi yang dimiliki oleh suatu materi atau unsur dalam kehidupan. Sumberdaya dapat berwujud sumberdaya manusia, yakni kompetensi implementor, dan sumberdaya finansial

3. Disposisi adalah watak dan karakteristik yang dimiliki oleh implementor.

4. Struktur Birokrasi Salah satu dari aspek struktur yang penting dari setiap organisasi adalah adanya prosedur operasi yang standar (standard operating procedures atau SOP) dan Fragmentasi.

\section{Faktor-faktor yang Mempengaruhi Implementasi Program BPNT Kecamatan Kanigaran Kota Probolinggo}

1. Komunikasi, Peneliti membahas fenomena komunikasi dengan memperhatikan transmisi, kejelasan dan konsistensi yang disesuaikan dengan hasil penelitian yaitu sebagai berikut:

a) Transmisi dari aparatur kepada penerima/pelaksana program BPNT Transmisi komunikasi atau penyaluran komunikasi yang baik akan menghasilkan suatu implementasi yang baik pula. Langkah awal dalam penyampaian informasi ini merupakan langkah penting agar pelaksana ataupun penerima mengetahui isi dari Program BPNT. Transmisi dalam program BPNT disampaikan dengan cara sosialisasi. Hasil interview yang dilakukan oleh peneliti dapat kita ketahui bahwa telah adanya sosialisasi yang dilakukan oleh para tim pelaksana Program BPNT. Sosialisasi dilakukan sampai ke titik distribusi dan rumah tangga sasaran. Sehingga diharapkan sampai ke rumah tangga sasaran memahami isi dari Program BPNT yang dijalankan.

b) Kejelasan akan kebijakan/program BPNT George Edwards III (Agustino, 2006: 150) menyatakan kejelasan komunikasi yang diterima oleh para pelaksana haruslah jelas dan tidak membingungkan masyarakat. Ketidakjelasan program tidak selalu menghalangi implementasi pada tataran tertentu para pelaksana membutuhkan fleksibilitas dalam 
melaksanakan kebijakan. Berdasarkan interview yang dilakukan oleh peneliti diketahui bahwa kendala dari rendahnya tingkat pendidikan masyarakat Kelurahan Kanigaran sehingga mengakibatkan pemahaman tentang program BPNT sangat kurang. Minimnya pengetahuan masyarakat tentang informasi program BPNT. (c). Konsistensi Berdasarkan hasil interview yang dilakukan oleh peneliti dapat kita ketahui bahwa informasi yang diberikan oleh atasan sudah konsisten. Jika ada informasi yang baru, langsung disampaikan kepada koordinator yang bersangkutan. Kemudian koordinator menyampaikan lagi hingga informasi tersebut sampai ke rumah tangga sasaran.

\section{Sikap (Disposisi)}

a) Penerimaan masyarakat terhadap implementasi program BPNT Masyarakat yang tergolong masyarakat sangat miskin menjadi kelompok sasaran (target group) dalam Implementasi Program BPNT. Berdasarkan hasil interview yang dilakukan peneliti menunjukan bahwa penerima manfaat raskin di Kelurahan Kanigaran merasa senang dengan adanya program BPNT. Sehingga manfaat dari bantuan BPNT dapat dirasakan oleh masyarakat.

b) Kepuasan terhadap Penggunaan BPNT Indikator keberhasilan program ini ada 6 tepat yaitu tepat sasaran, tepat jumlah, tepat harga, tepat waktu, tepat administrasi dan tepat kualitas. Hasil interview yang dilakukan peneliti dapat diketahui bahwa penerima BPNT merasa kurang puas dikarenakan masih ada kekurangan dalam pelaksanaan program BPNT. Program BPNT yang berjalan di Kecamatan Kanigaran Kota Probolinggo masih dirasa belum tepat kualitas, tidak tepat sasaran dan tidak tepat jumlah.

3. Sumber Daya

a) Staf Staf adalah dalam sebuah era dimana "pemerintah besar" berada dalam serangan dari semua arahan, hal ini mungkin nampak mengejutkan untuk belajar bahwa sebuah sumber pokok kegagalan implementasi adalah staf yang tidak cukup (dalam Tangkilisan, 2003:56). Hasil interview yang dilakukan oleh peneliti dapat diketahui bahwa sumberdaya manusia yang dimiliki oleh tim pelaksana masing-masing tingkat sudah memadai. Apalagi dengan adanya bantuan dari tim koordinasi wilayah setempat. Hal ini bisa mempermudah pelaksanaan program BPNT di Kecamatan Kanigaran Kota Probolinggo.

b) Kesediaan fasilitas Seorang implementor mungkin memiliki staf cukup, mungkin memahami apa yang ia duga harus dikerjakan, mungkin memiliki otoritas untuk mengamalkan tugasnya, namun tanpa bangunan perlu, peralatan, persediaan, dan bahkan implementasi ruang hijau tidak akan berhasil (Tangkilisan, 2009:83). Hasil interview yang dilakukan oleh peneliti diketahui bahwa fasilitas yang disediakan untuk pelaksanaan program raskin dinilai sudah memadai.

4. Struktur Birokrasi merupakan aspek yang penting dalam pelasanaan program ini, SOP atau prosedur-prosedur kerja dalam pelaksanaan program ini berjalan sebagaimana mestinya sesuai dengan aturan-aturan yang ditetapkan. Hasil interview yang dilakukan oleh peneliti dapat diketahui bahwa program BPNT ini juga didukung oleh berbagai pihak, dimana struktur birokrasi memiliki peranan dalam pelaksanaan program ini. sumber-sumber pelaksana serta bekerjanya organisasi-organisasi pelaksana program ini sudah cukup menunjang. Sedangkan fragmentasi pada pelaksanaan program ini cukup mendapat perhatian dan control langsung dari pihak-pihak pihak Kelurahan, Kecamatan, pemerintah Kota serta DPDR Kota Probolinggo, sehingga pelaksanaan program dapat berjalan dengan baik. 


\section{PENUTUP}

Simpulan Berdasarkan penelitian yang diperoleh dan Implementasi Program Bantuan Pangan Non Tunai (BPNT) melalui E-Warong di Kecamatan Kanigaran Kota Probolinggo dengan menggunakan teori Van Meter Van Horn adalah ukuran dan tujuan kebijakan juga menjelaskan bagaimana implementasi suatu kebijakan dilaksanakan. Tujuan kebijakan menjadi penting karena menyangkut alasan mengapa kebijakan tersebut dikeluarkan dan apa alasannya kebijakan itu dibuat. Akan tetapi Masyarakat hanya mengetahui garis besarnya saja jika bantuan tersebuat mendapatkan bantuan berupa bahan pangan. Sedangkan pada tujuan sudah tertera bahwa ada beberapa tujuan pemerintah dalam program ini. Tujuan program Bantuan Pangan ini belum berjalan dengan semestinya karena ada salah satu tujuan yaitu meningkatkan ketetapan sasaran dan waktu penerimaan Bantuan Pangan bagi KPM. Sumber daya merupakan elemen yang sangat penting dalam menjalankan sebuah kebijakan publik dan hal yang menjadi sangat krusial adalah sumber daya. Adapun sumber daya yang mempengaruhi implementasi adalah sumber daya manusia, financial dan waktu. Keberhasilan implementasi memerlukan keempat sumberdaya tersebut. Sumber daya manusia yang menjalankan pelaksanaan program Bantuan Pangan Non Tunai (BPNT) melalui E-Warong \& RPK di Kecamatan Kanigaran Kota Probolinggo. Sumber daya manusia yang menjalan program Bantuan Pangan Non Tunai (BPNT) melalui E-Warong \& RPK di Kecamatan Kanigaran Kota Probolinggo yaitu Koordinator Teknis, Pendamping BPNT serta masyarakat setempat. Sumber daya finansial atau dana pada program Bantuan Pangan Non Tunai ini berasal dari Kementrian Sosial yang langsung di transfer ke rekening-rekening KPM sebesar Rp 110.000,-/ bulan.

Kondisi Sosial, ekonomi dan politik dapat mempengaruhi jalannya suatu kebijakan. Karena keadaan sosial, ekonomi dan politik dapat mendukung bahkan sabaliknya. Di Kecamatan Kanigaran Kota Probolinggo keadaan sosialnya masih bisa dikatakan belum baik karena masih terdapat banyak warga penerima yang memiliki pendidikan rendah dan buta huruf sehingga dalam melakukan transaksi program Bantuan Pangan Non Tunai (BPNT) melalui E-Warong \& RPK di Kecamatan Kanigaran Kota Probolinggo mengalami kesulitan. Untuk keadaan ekonomi warga Kecamatan Kanigaran Kota Probolinggo masih bisa dikatakan stabil dan keadaan politik di Kecamatan Kanigaran Kota Probolinggo juga tidak mengalami masalah. Disposisi implementor bahwa pihak-pihak yang terlibat memberikan respon yang baik terhadap pelaksanaan program Bantuan Pangan Non Tunai (BPNT) melalui E-Warong \& RPK di Kecamatan Kanigaran Kota Probolinggo yang nantinya dapat mencapai tujuan dengan baik. Semua pelaksana yang terlibat sebenarnya sudah menjalankan tupoksinya masing- masing hanya saja ada pihak implementor enggan melakukan tugas yang diembannya. Justru yang dilakukan salah satu implementor adalah hal yang menyimpang. Hal ini tidak dapat melakukan salah satu poin pada disposisi implementor respon implementor terhadap kebijakan yang akan mempengaruhi kemauannya untuk melaksanakan kebijakan. Implementor yang lain juga bersikap tidak bertanggung jawab atas tugasnya. Sehingga masalah yang terjadi pada mesin EDC menjadi keluhan masyarakat.

Saran Dari hasil uraian tentang Bantuan Pangan Non Tunai (BPNT) melalui E-Warong \& RPK di Kecamatan Kanigaran Kota Probolinggo dalam proses implementasinya menemui beberapa permasalahan maka perlu adanya beberapa hal yang perlu di diperbaiki. Adapun saran yang dapat diajukan peneliti untuk peningkatan Implementasi Bantuan Pangan Non Tunai (BPNT) melalui E- Warung \& RPK di Kecamatan Kanigaran Kota Probolinggo adalah sebagai berikut: 
1. Perlu adanya koordinasi yang baik oleh pihak pelaksana dan stake holder sehingga tidak akan terjadi ketidak validan data.

2. Perlu adanya tanggapan yang cepat oleh petugas tekait dalam menangani masalah fasilitas mesin EDC.

3. Perlu adanya evalusi terkait implementor yang tidak dapat menerapkan sikap pelayanan publik yang baik.

4. Perlu adanya pendampingan yang lebih mengenai kondisi sosial yang kurang mendukung dengan diadakannya program Bantuan Pangan Non Tunai (BPNT).

5. Perlu adanya transparansi dan pangawasan yang lebih ketat agar tidak terjadi penyimpangan Untuk sumber daya dana sudah sesuai dengan yang ditentukan dalam pedoman pelaksanaan Bantauan Pangan Non Tunai (BPNT). Sumber daya waktu untuk pelaksanaan Bantuan Pangan Non Tunai sudah efektif. Karena uang yang tersalurkan setiap bulan tidak ada kendala. Sumber daya fasilitias sendiri mengalami kendala yaitu pada mesin EDC yang sering terjadi gangguan, sehingga proses implementasi terganggu. Dan dapat menjadi faktor penghambat jalannya implementasi Bantuan Pangan Non Tunai (BPNT) Komunikasi antar organisasi terdapat dua indikator, yaitu koordinasi dan komunikasi. Sosialisasi yang dilakukan oleh para pihak aktor pelaksana sudah dilaksanakan dengan baik dan berkelanjutan yaitu sebelum diluncurkannya program Bantuan Pangan Non Tunai (BPNT) melalui E-Warong di Kecamatan Kanigaran Kota Probolinggo dan sosialisasi setiap bulan oleh pihak pendamping kepada kelompok sasaran. Sehingga komunikasi dalam program Bantuan Pangan Non Tunai (BPNT) melalui EWarong di Kecamatan Kanigaran Kota Probolinggo oleh Kementrian Sosial, Dinas, Kelurahan dan kelopok sasaran sudah berjalan dengan baik. Karakteristik agen pelaksana yang mendukung berjalannya program Bantuan Pangan Non Tunai (BPNT) melalui EWarong di Kecamatan Kanigaran Kota Probolinggo adalah disiplin, ramah, bertanggung dan memiliki jiwa sosial yang tinggi. Kedisiplinan pelaksana tercermin dari kesigapan dalam menjalankan program program Bantuan Pangan Non Tunai (BPNT) melalui EWarong di Kecamatan Kanigaran Kota Probolinggo dengan tepat waktu. sikap ramah, bertanggung jawab dan jiwa sosial yang tinggi juga tercermin dalam jiwa aktor pelaksana dalam menjalankan program ini. Akan tetapi ada satu aktor yang tidak menerapkan sifat ramah dan sopan sesuai dengan sifat yang tertera dalam UU No. 25 Tahun 2009. Sehingga dapat menjadi hambatan dalam berjalannya program ini.

\section{DAFTAR PUSTAKA}

Adi, Isbandi Rukminto. 2003. Pemberdayaan, Pengembangan Masyarakat dan Intervensi Komunitas (Pengantar Pada Pemikiran dan Pendekatan Praktis). Cet. I. Jakarta: Lembaga Penerbit FEUI.

Agustino, Leo. 2009. Dasar-Dasar Kebijakan Publik. Bandung: Alfabeta.

Badjuri, Abdul Kahar dan Teguh Yuwono. 2002. Kebijakan Publik (Konsep dan Strategi). Semarang: Jurusan Ilmu Pemerintahan FISIP UNDIP.

Kementerian Koordinator Bidang Kesejahteraan Rakyat Republik Indonesia,Pedoman Umum Raskin beras bersubsidi untuk rumah tangga miskin. Jakarta, 2011

Moleong, Lexy J. 2011. Metode Penelitian Kualitatif edisi Revisi. Bandung: PT. Remaja Rosdakarya 
Nugroho D, Riant. 2006. Kebijakan Publik Untuk Negara-Negara Berkembang. Jakarta: PT Elex Media Komputindo.

. 2011. Public Policy. Jakarta : PT Elex Komputindo

Pedoman Umum BPNT 2018 http://tnp2k.go.id/program/klaster-i-2/

Solichin, Abdul Wahab. 2001. Analisis Kebijaksanaan Dari Formulasi Ke Implementasi Kebijaksanaan Negara. Jakarta: Bumi Aksara.

Subarsono, AG. 2010. Analisis Kebijakan Publik (Konsep, Teori dan Aplikasi). Yogyakarta: Pustaka Pelajar.

Suwitri, Sri. 2008. Konsep Dasar Kebijakan Publik. Semarang: Badan Penerbit Universitas Diponegoro.

Tangkilisan, Hessel Nogi S. 2003. Implementasi Kebijakan Publik. Yogyakarta: YPAPI. 